\title{
PENGEMBANGAN ALAT PERAGA SEBAGAI MEDIA PEMBELAJARAN PENERAPAN KONSEP HUKUM PASCAL UNTUK PESERTA DIDIK KELAS VIII DI SMP NEGERI 1 SITIMSEL
}

\author{
Rini Pangke, Jeane Cornelda Rene, Alfrits Komansilan \\ Fakultas Matematika dan Ilmu Pengetahuan Alam, Universitas Negeri Manado \\ email: rinip150999@gmail.com
}

\begin{abstract}
ABSTRAK
Media pembelajaran berupa alat peraga sangat penting bagi proses pembelajaran fisika karena pembelajaran yang menggunakan alat peraga dapat membantu peserta didik lebih mudah memahami konsep yang sedang dipelajari. Tujuan penelitian ini untuk mengembangkan alat peraga sebagai media pembelajaran penerapan konsep hukum Pascal untuk peserta didik kelas VIII di SMP Negeri 1 Sitimsel dan mengetahui keefektifan alat peraga sebagai media pembelajaran penerapan konsep hukum Pascal untuk peserta didik kelas VIII di SMP Negeri 1 Sitimsel. Jenis penelitian ini adalah Research and Development $(R \& D)$ menurut Sugiyono dan subjek penelitian adalah 5 orang peserta didik kelas VIII A dan 21 orang peserta didik kelas VIII B. Hasil penelitian menujukkan proses pengembangan alat peraga sebagai media pembelajaran meliputi analisis potensi dan masalah, pengumpulan data, desain produk, validasi desain, revisi desain, uji coba awal, revisi produk, uji coba pemakaian, revisi produk dan produksi masal dan keefektifan alat peraga sebagai media pembelajaran penerapan konsep hukum Pascal untuk peserta didik kelas VIII di SMP Negeri 1 Sitimsel, dilihat dari hasil analisis uji Gain ternormalisasi pada uji kelompok kecil sebesar 0,9 dan uji kelompok besar sebesar 0,92 hal ini termasuk dalam kriteria tinggi, sehingga alat peraga efektif dalam meningkatan pemahaman konsep perserta didik.
\end{abstract}

Kata kunci : Alat peraga, media pembelajaran, Hukum Pascal

\begin{abstract}
Learning media in the form of teaching aids is very important in the physics learning process, as learning with teaching aids can help students more easily understand the concepts under study. The aim of this study was to develop teaching materials as a learning medium for the application of the Pascal law concept for class VIII students at SMP Negeri 1 Sitimsel and to examine the effectiveness of teaching materials as a learning medium for the application of the Pascal law concept for class VIII students at SMP Negeri 1 sitimsel. This type of research is research and development $(R \& D)$ according to Sugiyono and the research topics are 5 students in class VIII A and 21 students in class VIII B. The results of the research show the process of developing teaching materials as a learning medium including potential and Problem analysis, design product, design validation, revised design, first attempts, product attempts, use attempts, product revisions and mass production as well as the effectiveness of teaching materials as a learning medium for the application of Pascal's legal concepts for pupils of class VIII at SMP Negeri 1 Sitimsel, from the results shown normalized reinforcement test analysis in the small group test of 0.9 and large group test of 0.92, this is included in the high criteria, so the props are effective in enhancing students' conceptual understanding.
\end{abstract}

Keywords $\quad$ : teaching aids, learning media, Pascal's law 


\section{PENDAHULUAN}

Pendidikan merupakan salah satu bidang Setiap mata pelajaran disekolah memiliki ciriciri yang berbeda dengan mata pelajaran lainnya. Dengan demikian masing-masing mata pelajaran juga memerlukan media pembelajaran atau sarana pembelajaran yang berbeda pula. Dalam proses belajar mengajar tenaga pendidik pastinya memerlukan media pembelajaran yang dapat mendukung kinerjanya sehingga pembelajaran dapat berlangsung dengan menarik (Hani, 2017).

Fisika adalah ilmu yang mempelajari tentang gejala-gejala, kejadian-kejadian serta interaksi yang terjadi di alam. Fisika juga merupakan sekumpulan dari fakta, konsep, hukum/prinsip, persamaan dan teori. Fisika adalah salah satu mata pelajaran yang tidak hanya menekankan pada konsep, tetapi juga pada praktek. Alat peraga menjadi salah satu bagian yang dapat mengantarkan konsep yang abstrak menjadi lebih konkrit. Pada pelajaran Fisika peserta didik mampu menggali kreativitas dengan menerapkan konsep yang ada dalam materi pembelajaran fisika, namun pada kenyataanya tidak semua materi dalam mata pelajaran fisika dapat dilakukan hanya dengan pemahaman konsep saja akan tetapi didukung dengan adanya media pembelajaran seperti alat peraga sehingga dapat memberikan efek senang, semangat, dan pemahaman contoh penerapan ilmu fisika dalam kehidupan seharihari (Hani, 2017).

Media pembelajaran merupakan sarana untuk meningkatkan suatu kegiatan belajar mengajar. Media pembelajaran digunakan dalam rangka berkomunikasi dan berinteraksi antara guru dan siswa dalam proses pembelajaran (Kustandi \& Darmawan, 2020).

Media pembelajaran berupa alat peraga sangat penting bagi proses pembelajaran fisika karena pembelajaran yang menggunakan alat peraga dapat membantu peserta didik lebih mudah memahami konsep yang sedang dipelajari. Dari hal tersebut, diperlukan media pembelajaran untuk membantu kegiatan proses belajar-mengajar dikelas. Peserta didik perlu diberikan kegiatan mengamati dan eksperimen agar peserta didik memiiki pengalaman langsung dalam pembelajaran (Sobari \& Sucahyo, 2016). Sesuai dengan pernyataan dari Alatas dan Astuti bahwa bahwa alat peraga dibutuhkan oleh peserta didik agar dapat lebih memahami konsep yang dipelajari dalam pembelajaran fisika (Alatas \& Astuti, 2019).

Hasil observasi awal terhadap 15 siswa kelas VIII SMP N 1 Sitimsel yang telah diberikan angket secara daring dari 12 diantaranya sulit memahami konsep fisika saat pembelajaran berlangsung sehingga ada anggapan bahwa fisika adalah mata pelajaran yang sulit dan kurangnya penggunaan media pembelajaran yang menarik bagi peserta didik karena belum tersedianya alat peraga sederhana untuk penerapan materi yang disajikan sehingga dapat memudahkan peserta didik dalam memahami materi fisika dan hasil observasi di laboratorium IPA SMP Negeri 1 Sitimsel didapatkan bahwa belum ada alat peraga sebagai media pembelajaran fisika khususnya pada materi tekanan zat cair topik hukum Pascal, sehingga dilakukan penelitian dengan mengembangkan alat peraga sebagai media pembelajaran penerapan hukum Pascal berupa lengan robot hidrolik sederhana dan alat pengangkat mobil sederhana.

Lengan robot hidrolik sederhana dan alat pengangkat mobil sederhana adalah alat peraga sederhana yang dapat membantu peserta didik memahami konsep hukum Pascal. Pada materi hukum Pascal peserta didik diberikan materi tentang konsep tekanan dari alat peraga berupa lengan robot hidrolik sederhana dan alat pengangkat mobil sederhana sehingga peserta didik lebih tertarik untuk belajar. Alat peraga ini digunakan di SMP karena sesuai dengan kondisi peserta didik SMP yang masih menyukai hal-hal baru dan yang berkaitan dengan keterampilan.

Berdasarkan latar belakang masalah yang sudah dipaparkan diatas maka dilakukan penelitian dengan judul "Pengembangan Alat Peraga Sebagai Media Pembelajaran Penerapan Konsep Hukum Pascal untuk Peserta Didik Kelas VIII di SMP Negeri 1 Sitimsel”. Adapun tujuan dilakukannya penelitian ini adalah: (1) mengembangkan alat peraga sebagai media pembelajaran penerapan konsep hukum Pascal untuk peserta didik kelas VIII di SMP Negeri 1 Sitimsel; (2) mengetahui keefektivan alat peraga sebagai media pembelajaran penerapan konsep hukum pascal untuk peserta didik kelas VIII di SMP Negeri 1 Sitimsel.

\section{METODE PENELITIAN}

Penelitian ini menggunakan metode research and development $(R \& D)$ mengikuti 
langkah-langkah penelitian dan pengembangan menurut (Sugiyono, 2019). Metode penelitian ini digunakan untuk menghasilkan produk tertentu dan menguji keefektifan produk tersebut. Untuk dapat menghasilkan produk tertentu digunakan penelitian yang bersifat analisis validasi kelayakan dari ahli media dan ahli materi serta analsis keefektifan produk yang dikembangkan.

Langkah-Langkah penelitian dan pengembangan meliputi potensi dan masalah, pengumpulan data, desain produk, validasi desain, revisi desain, uji coba awal, revisi produk, uji coba pemakaian, revisi produk dan produksi masal. Penelitian ini dilaksanakan secara luring karena adanya Covid-19 yang beralamat di Kampung Biau Seha, Kecamatan Siau Timur Selatan, Kabupaten Siau Tagulandang Biaro. Subjek penelitian ini adalah peserta didik kelas VIII A dan B SMP Negeri 1 Siau Timur Selatan tahun ajaran 20202021.

\section{Instrumen Pengumpulan Data}

Instrumen pengumpulan data dalam penelitian ini berupa angket validasi ahli media, ahli materi guru IPA serta test berupa pretest dan posttest untuk uji kelompok kecil dan uji kelompok besar

\section{Teknik Pengumpulan Data}

Ada empat tahap dalam pengumpulan data untuk mengembangkan alat peraga sebagai media pembelajaran yaitu observasi, angket, tes dan dokumentasi.

\section{Teknik Analisis Data}

Data yang diperoleh akan di analisis secara kuantitatif. Analisis kuantitatif ini dilakukan untuk melihat kulitas produk yang sudah dikembangkan berdasarkan kelayakan dan keefektifan produk tersebut.

Untuk menghitung rata-rata skor yang diperoleh dari angket validasi ahli media, ahli materi dan guru IPA digunakan untuk mengumpulkan data mengenai kelayakan alat peraga di dalam materi dan desain alat peraga yang telah dikembangangkan. Pertanyaan atau pernyataan dalam instrumen disesuaikan dengan media pembelajaran yang telah dikembangkan. Skor yang diperoleh dianalisis menggunakan skala Likert yang terdiri dari beberapa kategori sebagai berikut:
Tabel 1. Aturan Pemberian Skor

\begin{tabular}{lll}
\hline No & Kategori & Skor \\
\hline 1 & Sangat Setuju (SS) & 5 \\
\hline 2 & Setuju (S) & 4 \\
\hline 3 & Kurang Setuju (KS) & 3 \\
\hline 4 & Tidak Setuju (TS) & 2 \\
\hline 5 & Sangat Tidak Setuju (STS) & 1 \\
\hline
\end{tabular}

Analisis data dari angket validasi diperoleh berdasarkan tanggapan para ahli media, ahli materi dan guru IPA yang berupa skor dilakukan menggunakan presentase, dengan rumus sebagai berikut (Arikunto, 2010):

$$
\mathrm{P}=\frac{\sum x}{\sum x i} 100 \%
$$

Kriteria validitas yang digunakan dalam validitas penelitian dapat dilihat dalam tabel 2 sebagai berikut:

Tabel 2. Tingkat Pencapaian dan Kualitas Kelayakan

\begin{tabular}{cccc}
\hline Skor & $\begin{array}{c}\text { Tingkat } \\
\text { Pencapai } \\
\text { an }(\%)\end{array}$ & $\begin{array}{c}\text { Kualifika } \\
\text { si }\end{array}$ & Keterangan \\
\hline 5 & $81-100$ & $\begin{array}{c}\text { Sangat } \\
\text { Baik }\end{array}$ & $\begin{array}{c}\text { Sangat } \\
\text { Layak }\end{array}$ \\
\hline 4 & $61-80$ & Baik & Layak \\
\hline 3 & $41-60$ & Cukup & Kurang \\
& & Baik & Layak \\
\hline 2 & $21-40$ & $\begin{array}{c}\text { Kurang } \\
\text { Baik }\end{array}$ & $\begin{array}{c}\text { Tidak } \\
\text { Layak }\end{array}$ \\
\hline 1 & $0-20$ & $\begin{array}{c}\text { Sangat } \\
\text { Kurang } \\
\text { baik }\end{array}$ & $\begin{array}{c}\text { Sangat } \\
\text { Tidak } \\
\text { Layak }\end{array}$ \\
\hline
\end{tabular}

Media Pembelajaran dikatakan layak apabila mencapai presentase minimal $61 \%$ dalam kulitas baik atau layak. Sehingga produk dapat digunakan sebagai media pembelajaran di SMP.

Analisis keefektifan alat peraga melalui peningkatan pemahaman konsep peserta didik dilihat dari hasil pretest dan posttest. Untuk mengetahui peningkatan pemahaman konsep sebelum dan sesudah pembelajaran, dapat dianalisis dengan Uji Gain Ternormalisasi <g>. 


$$
<g>=\frac{(\text { Spost }- \text { Spre })}{\text { Skor maksimum }-(\text { Spre })}
$$

Kemudian hasilnya dikategorikan dalam tabel 3 berikut: (Maliasih, dkk., 2015).

\begin{tabular}{c} 
Tabel 2. Kriteria Uji Gain Ternormalisasi \\
\hline G
\end{tabular}

\section{HASIL DAN PEMBAHASAN}

Berdasarkan rancangan pengembangan maka hasil penelitian disesuaikan dengan langkah-langkah pengembangan menurut Sugiyono. Data hasil dari tahapan prosedur penelitian dan pengembangan yang dilakukan adalah sebagai berikut:

\section{Analisis Potensi dan Masalah}

Hasil dari tahap pendefinisian adalah Masalah yang terjadi dilapangan melalui indetifikasi potensi masalah yang ada disekolah baik laboratorium IPA dan pemberian angket kepada peserta didik secara daring, disimpulkan bahwa masalah yang terjadi adalah peserta didik sulit memahami konsep fisika saat pembelajaran berlangsung sehingga ada anggapan bahwa fisika adalah mata pelajaran yang sulit dan belum tersedianya alat peraga untuk penerapan materi yang disajikan sehingga dapat memudahkan peserta didik dalam memahami materi Fisika.

\section{Pengumpulan Data}

Dalam proses pengumpulan data dilakukan setelah menganalisis permasalahan yang terjadi di lapangan dan alat peraga yang dapat mengatasi masalah-masalah tersebut. Data dan informasi mengenai alat peraga baik berupa jurnal-jurnal, internet dan lain-lain dikumpulkan dan diolah sehingga menghasilkan beberapa produk alat peraga untuk penerapan konsep hukum Pascal.

\section{Desain Produk}

Alat peraga lengan robot hidrolik sederhana dan alat pengangkat mobil sederhana didesain untuk menjelaskan konsep fisika khususnya mengenai penerapan konsep hukum Pascal.
- Tampak Depan

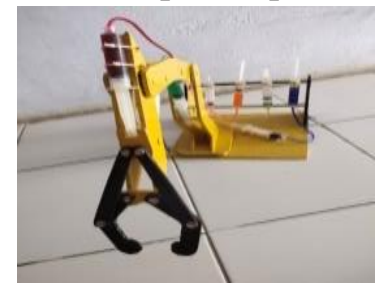

Gambar 1. Tampak depan alat peraga lengan robot hidrolik sederhana

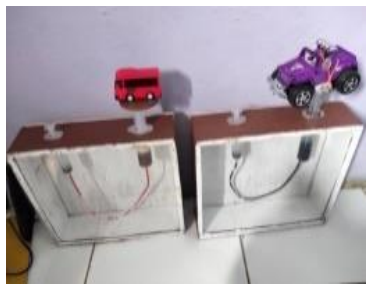

Gambar 2. Tampak depan alat peraga pengangkat mobil sederhana
- Tampak Samping Kanan

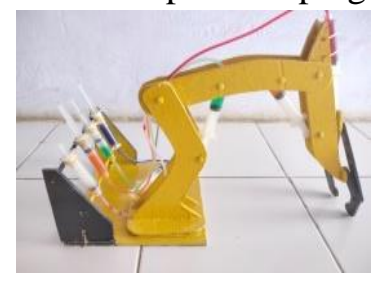

Gambar 3. Tampak kanan alat peraga lengan robot hidrolik sederhana

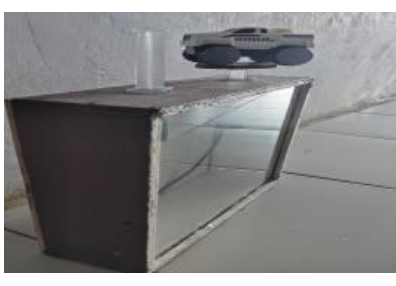

Gambar 4. Tampak kanan alat peraga pengangkat mobil sederhana
- Tampak Samping Kiri

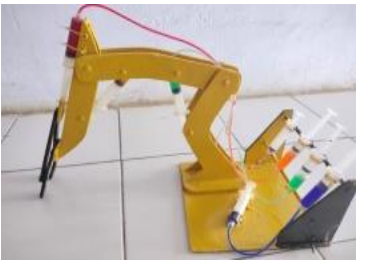

Gambar 5. Tampak kiri alat peraga lengan robot hidrolik sederhana

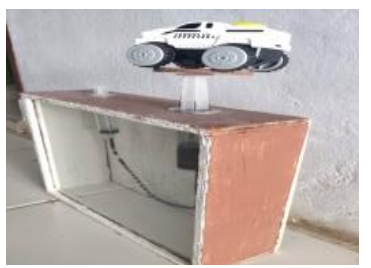

Gambar 6. Tampak kiri alat peraga pengangkat mobil sederhana

\section{Validasi Desain}

Setelah desain produk langkah selanjutnya yaitu melakukan uji kelayakan rancangan produk. Dalam tahap ini divalidasi oleh pakar/ahli 2 orang dosen dan 1 orang guru IPA.

a) Validasi ahli media

Validasi ahli media dilakukan oleh Drs. Jimmy Lolowang, M.Si selaku dosen fisika unima. Validasi ini dilakukan dengan mengisi instrumen penilaian dengan 6 aspek penilaian yaitu: aspek keterkaitan dengan bahan ajar, aspek nilai pendidikan, aspek ketahanan alat peraga, aspek efisiensi alat peraga, aspek keamanan bagi peserta didik dan aspek estetika. Validasi oleh ahli media ini dilakukan 3 kali pertemuan yang bertujuan untuk melihat kelayakan alat peraga yang telah dikembangkan. Hasil validasi oleh ahli media disajikan pada diagram batang sebagai berikut: 


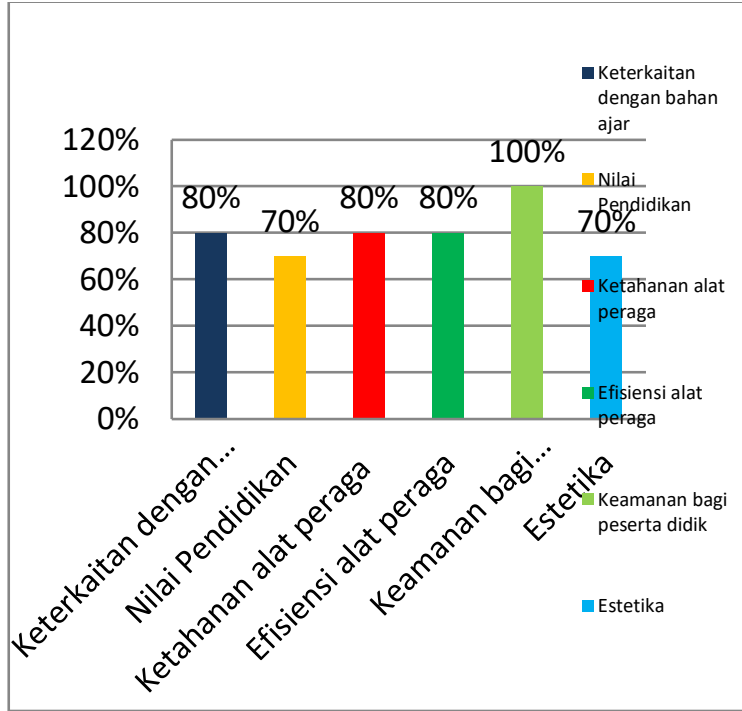

Gambar 7. Diagram Batang Hasil Validasi Pertemuan I

Dari gambar 7 diatas hasil validasi alat peraga pada pertemuan I didapatkan rata- rata presentase dari tiap-tiap aspek adalah 80\% dalam kualifikasi baik dan dikategorikan layak namun perlu diperbaiki lagi. Berdasarkan grafik di atas maka diperoleh penilaian alat peraga sesuai dengan kondisi alat peraga yang divalidasi oleh ahli media.

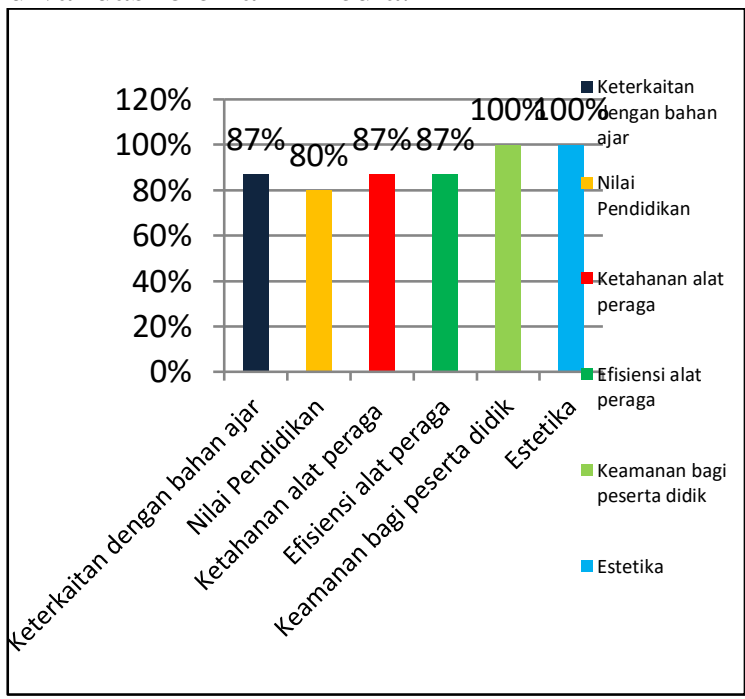

Gambar 8. Diagram Batang Hasil Validasi Pertemuan II

Dari gambar 8 di atas hasil validasi pertemuan II alat peraga telah direvisi sehingga hasil dari validasi alat peraga pada pertemuan II didapatkan rata- rata presentase dari tiap-tiap aspek adalah 90\% dikualifikasikan sangat baik dan dikategorikan sangat layak serta mengalami peningkatan dari validasi pertemuan I namun alat peraga perlu ditambah alat pengangkat mobil sederhana.

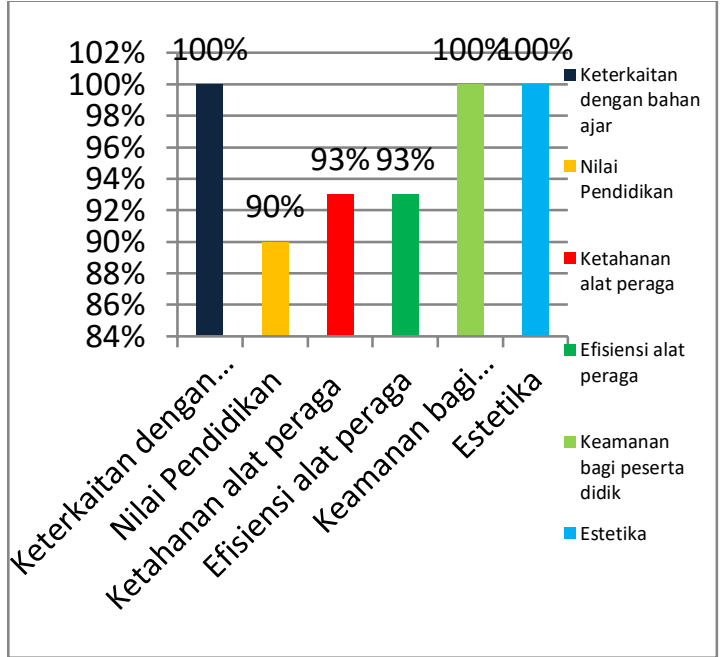

Gambar 9. Diagram Batang Hasil Validasi Pertemuan III

Dari gambar 9 di atas setelah ditambahkan alat peraga pengangkat mobil sederhana hasil dari validasi alat peraga pada pertemuan III didapatkan rata- rata presentase dari tiap-tiap aspek adalah 96\% dikategorikan sagat baik dan produk layak digunakan.

b) Validasi ahli materi

Validasi ahli materi dilakukan oleh Dr. Marianus, M.Si selaku dosen fisika unima. Validasi ini dilakukan dengan mengisi instrumen penilaian dengan aspek penilaian yaitu: aspek materi. Validasi oleh ahli materi ini dilakukan 1 kali pertemuan yang bertujuan untuk melihat kelayakan materi. Penilaian oleh ahli materi mendapatkan presentase kelayakan produk sebesar $98 \%$ dan sudah termasuk pada kriteria sangat baik dengan keterangan sangat layak.

c) Validasi guru IPA

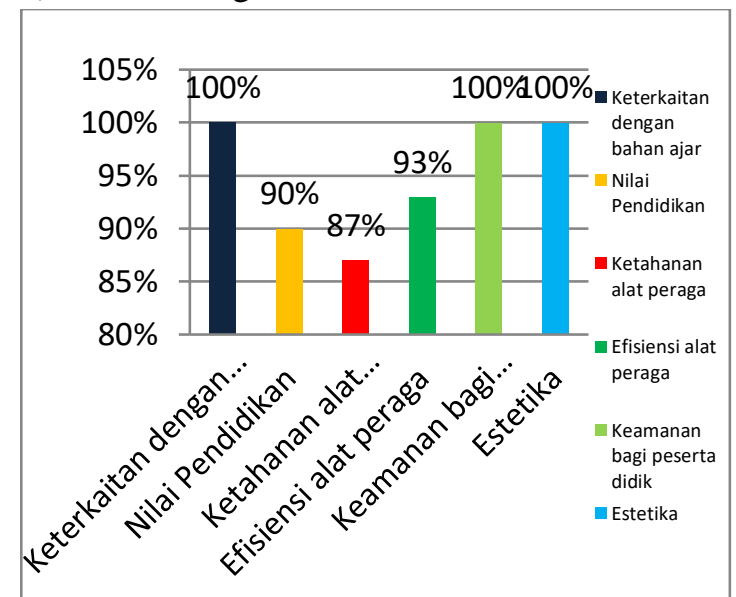

Gambar 10. Diagram Batang Hasil Validasi Guru IPA 
Dari gambar 10 di atas validasi yang dilakukan oleh guru IPA sebanyak 1 kali setelah produk divalidasi oleh ahli media dan ahli materi dan mendapatkan kelayakan presentase sebesar 95\% dalam kriteri sangat baik atau sangat layak.

\section{Revisi Desain}

Setelah dilakukan validasi oleh ahli media dan ahli materi, selanjutnya revisi terhadap desian produk yang telah dikembangkan berdasarkan saran perbaikan dari ahli media dan ahli materi tersebut. Saran peraikan dari ahli media adalah (1) Alat peraga diberi warna sesuai dengan fungsi; (2) warna zat cair pada dispo harus beragam agar mudah mengetahui fungsi dari keempat dispo tersebut; (3) tambahkan alat peraga alat pengangkat mobil sederhana. Untuk saran perbaikan dari ahli materi adalah (1) tambahkan penomoran persamaan; (2) tambahkan keterangan simbol pada gambar.

Hasil revisi dapat dilihat pada gambar dibawah ini:

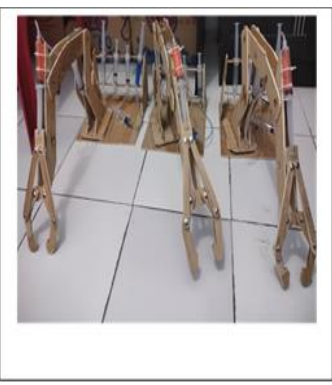

Gambar 11. Alat Peraga Sebelum direvisi

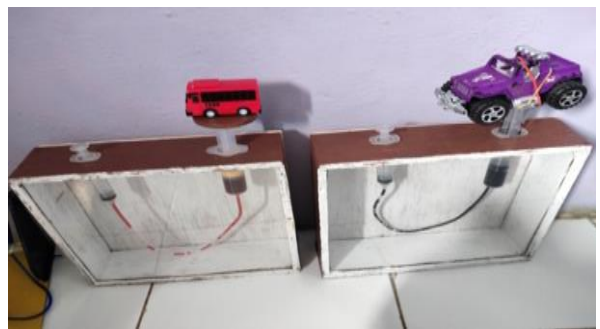

Gambar 13. Penambahaan Alat Peraga Pengangkat Mobil Sederhana

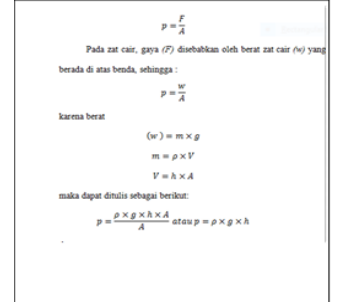

Gambar 14. Materi Sebelum direvisi

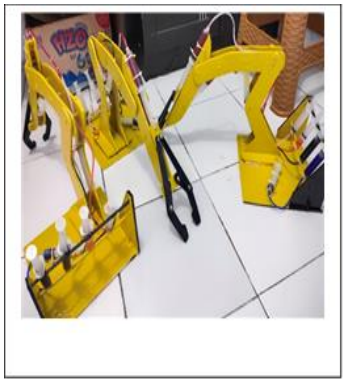

Gambar 12. Alat Peraga Sesudah direvisi 


\section{Uji Coba Pemakaian}

Pada tahap uji coba pemakaian atau uji coba kelompok besar dilakukan pada peserta didik kelas VIII B SMP Negeri 1 Siau Timur Selatan yang berjumlah 21 orang peserta didik secara luring karena adanya Covid-19 sehingga pembelajara di adakan secara luring dengan 2 sesi guna mencegah penyebaran Covid-19.

Sebelum memulai pembelajaran di bagikan pretest kepada masing-masing peserta didik untuk megetahui seberapa besar pemahaman konsep hukum Pascal yang dimiliki peserta didik, dan setelah pembelajaran dengan menggunakan alat peraga berakhir kembali di berikan posttest kepada masingmasing peserta didik guna mengetahui capaian pemahaman konsep materi hukum Pascal setelah pembelajaran menggunakan alat peraga. Hasil pretest dan posttes pada uji coba kelompok besar dapat dilihat pada gambar 19 sebagai berikut:

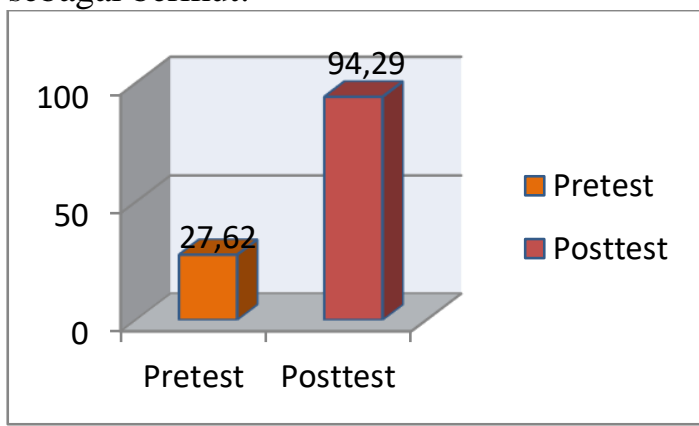

Gambar 19. Diagram Hasil Pretest dan Posttest Kelompok Besar

Berdasarkan nilai pretest dan posttest didapatkan nilai gain kelompok besar dalam pembelajaran dengan menggunakan alat peraga sebesar 0,92 termasuk dalam kriteria tinggi, sehingga alat peraga efektif dalam meningkatan pemahaman konsep perserta didik.

\section{Revisi Produk}

Pada saat uji kelompok besar produk mengalami kerusakan dan kelemahan maka produk hasus direvisi kembali. Hasil revisi dapat dilihat pada gambar-gambar dibawah ini:

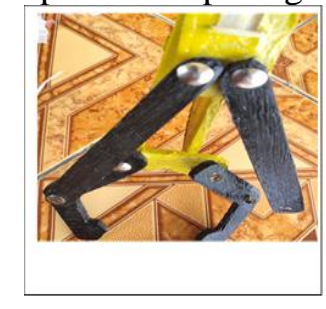

Gambar 20. Alat peraga sebelum direvisi

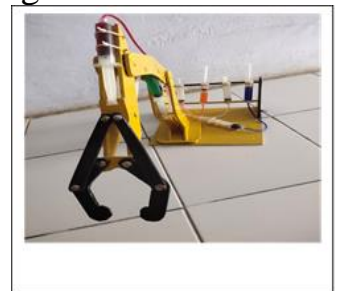

Gambar 21. Alat peraga sesudah direvisi

\section{Produksi Masal}

Produksi masal ini dilakukan dengan cara memberikan alat peraga yang telah dikembangkan kepada Laboratorium SMP Negeri 1 Sitimsel.

\section{KESIMPULAN}

Berdasarkan hasil analisis data dan pembahasan dari hasil penelitian yang telah dilakukan, diperoleh kesimpulan bahwa:

1. Proses pengembangan alat peraga sebagai media pembelajaran penerapan konsep hukum Pascal untuk peserta didik kelas VIII di SMP Negeri 1 Sitimsel menggunakan rancangan pendekatan penelitian dan pengembangan menurut Sugiyono yang meliputi analisis potensi dan masalah, pengumpulan data, desain produk, validasi desain, revisi desain, uji coba awal, revisi produk, uji coba pemakaian, revisi produk dan produksi masal.

2. Keefektifan alat peraga sebagai media pembelajaran penerapan konsep hukum Pascal untuk peserta didik kelas VIII di SMP Negeri 1 Sitimsel dilihat daru hasil analisis uji gain ternormalisasi pada uji kelompok kecil sebesar 0,9 dan uji kelompok besar sebesar 0,92 hal ini berarti termasuk dalam kriteria tinggi, sehingga alat peraga efektif dalam meningkatan pemahaman konsep perserta didik.

\section{REFERENSI}

Alatas, F., \& Astuti, W. (2019). Pengembangan Alat Peraga Sederhana pada Materi Fluida Statis Sebagai Media Pembelajaran Fisika. Jurnal Pendidikan Fisika, 7(2), 198-211.

Arikunto, P. (2010). Prosedur Penelitian Suatu Pendekatan Praktek. Jakarta: PT Rineka Cipta.

Hani, U. S. (2017). Pengembangan Media Pembelajaran sebagai Alat Peraga Penerapan Konsep Hukum Pascal untuk Peseta didik Kelas VIII di SMP. Skripsi. Jurusan Pendidikan Fisika Fakultas Matematika dan Ilmu Pengetahuan Alam, Universitas Islam Negeri Raden Intan Lampung.

Kustandi, C., \& Darmawan, D. (2020). Pengembangan Media Pembelajaran. Jakarta: Kencana. 
Maliasih. (2015). Pengembangan Alat Peraga

Kit Hidrostatis untuk Meningkatkan Pemahaman Konsep Tekanan Zat Cair pada Siswa SMP. Skripsi. Jurusan Fisika

Fakultas Matematika dan Ilmu Pengetahuan Alam, Universitas Negeri Semarang.

Sobari, A., \& Sucahyo, I. (2016). Pengembangan Alat Peraga Ticker Timer sebagai Media Pembelajaran Fisika Pokok Bahasan Gerak Lurus. Jurnal Inovasi Pendidikan Fisika (JIPF), 5(3), 154-160.

Sugiyono. (2019). Metode Penelitian Kuantitatif Kualitatif dan $R \& D$. Bandung: Alfabeta. 